\title{
THE FEDERAL BUDGET: RISK OF EXPENDITURE PATTERN DETERIORATION ${ }^{1}$
}

\author{
A.Mamedov, E.Fomina
}

In 2015, the federal budget was executed with a deficit of $2.7 \%$ of GDP (in $2014,0.5 \%$ of GDP). Compared to 2014, revenues have fallen significantly by 2.0 p.p. of GDP, expenditure volume has gone up slightly - by 0.2 p.p. of GDP. The year 2016 and the following medium-term period can become more frustrated for the budget and domestic economy as a whole, in the event there are no timely decisions regarding operational and strategic measures aimed and adjusting the budget system to the new normal. At the same time, renewal of the technical ten percent budget cut in the context of protected budget lines (social obligations, defense, public-sector employees' wages) lead to risks of further deterioration of the federal budget expenditure with decreased share of expenses, which contribute to the economic growth in the long-term (human capital and infrastructure).

According to the RF Treasury data, the federal budget revenues for 2015 (Table 1) have constituted $18.3 \%$ of GDP, down 2.0 p.p. of GDP compared to 2014 , what is more, this reduction is due to the fall of oil and gas revenues. In 2015, their volume was down 2.6 p.p. of GDP against 2014. Meanwhile, non-oil and gas revenues have reached around $10.3 \%$ of GDP up 0.6 p.p. of GDP against 2014. The volume of the federal budget expenditure has moved up insignificantly by 0.2 p.p. of GDP and came to $21.0 \%$ of GDP. On the whole, the federal budget during 2015 was executed with a deficit of $2.7 \%$ of GDP up 2.2 p.p. of GDP against 2014. At the same time, non-oil and gas deficit has come to $10.7 \%$ of GDP down 0.4 p.p. of GDP compared to 2014.

During 2015, with macroeconomic outlook deterioration the 2015 federal budget framework was revised ${ }^{2}$. Considering volatility of the main macroeconomic indicators and difficulties related to their forecasting, one-year federal budget was approved for 2016 (as it was with 2010 budget). In autumn 2015, the 2016 federal budget framework was subject to significant revisions against the original budget framework approved in the Law on the Federal Budget for 2015-2017. Largely revisions affected the resource base of the federal budget, reduction constituted 1.5 p.p. of GDP (17.5\% of GDP) against the original framework. The decrease of the federal budget revenues was due to further projected decline of oil and gas budget revenues to $7.7 \%$ of GDP (against $9.7 \%$ of GDP) resulting from the fall of crude oil prices.

In the original medium-term forecast, the federal budget revenues in 2016 were calculated on an assumption of oil price at $\$ 96$ per barrel, meanwhile

1 This paper was originally published in Online Monitoring of Russia's Economic Outlook No.2(20).

2 In March 2016, amendments were adopted due to the revisions of main macroeconomic indicators allowed for the 2015 budget projections. According to the adjustments, the price of crude fell from $\$ 87.6$ to $\$ 50$ per barrel, ruble exchange rate cut from 37.97 to 61.5 to the dollar, inflation rate up from 5.5 to $12.2 \%$. As a result of adopted changes, the revenues forecast down 0.6 p.p. of GDP, and spending plan up 0.8 p.p. of GDP. As a result, the budget deficit moved up to $3 \%$ of GDP (growth 3.1 p.p. of GDP). 
MAIN PARAMETERS OF THE FEDERAL BUDGET FOR 2014-2016

\begin{tabular}{|c|c|c|c|c|c|c|c|c|c|c|c|}
\hline & \multicolumn{7}{|c|}{ Actual execution } & \multirow[b]{2}{*}{ 닐 } & \multicolumn{2}{|c|}{2016} & \multirow{2}{*}{ 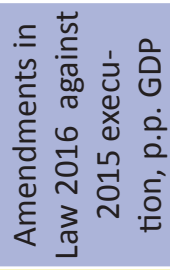 } \\
\hline & 2008 & 2009 & 2010 & 2011 & 2012 & 2013 & 2014 & & 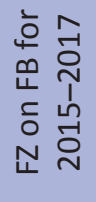 & 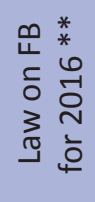 & \\
\hline Revenues, & 22.3 & 18.9 & 17.9 & 20.3 & 20.7 & 19.7 & 20.3 & 18.3 & 19.0 & 17.5 & -0.8 \\
\hline \multicolumn{12}{|l|}{ of which: } \\
\hline $\begin{array}{l}\text { Oil and gas } \\
\text { revenues }\end{array}$ & 10.8 & 7.8 & 8.3 & 10.4 & 10.7 & 10.1 & 10.6 & 8.0 & 9.7 & 7.7 & -0.3 \\
\hline $\begin{array}{l}\text { Non-oil and } \\
\text { gas revenues }\end{array}$ & 11.5 & 11.1 & 9.6 & 9.9 & 10.0 & 9.6 & 9.7 & 10.3 & 9.3 & 9.8 & -0.5 \\
\hline Expenditures, & 18.2 & 24.8 & 21.8 & 19.5 & 20.7 & 20.2 & 20.8 & 21.0 & 19.6 & 20.5 & -0.5 \\
\hline $\begin{array}{l}\text { of which: } \\
\text { conditionally } \\
\text { approved }\end{array}$ & 0 & 0 & 0 & 0 & 0 & 0 & 0 & 0 & 0.5 & 0.0 & 0.0 \\
\hline $\begin{array}{l}\text { deficit (-) / } \\
\text { surplus (+) }\end{array}$ & 4.1 & -5.9 & -3.9 & 0.8 & 0 & -0.5 & -0.5 & -2.7 & -0.6 & -3.0 & -0.3 \\
\hline $\begin{array}{l}\text { Non-oil and } \\
\text { gas deficit }\end{array}$ & -6.7 & -13.7 & -12.2 & -9.6 & -10.7 & -10.6 & -11.1 & -10.7 & -10.3 & -10.7 & 0.0 \\
\hline GDP, Rb bn & $\begin{array}{c}41 \\
277\end{array}$ & $\begin{array}{c}38 \\
807\end{array}$ & $\begin{array}{c}46 \\
309\end{array}$ & $\begin{array}{c}55 \\
967\end{array}$ & $\begin{array}{c}62 \\
177\end{array}$ & $\begin{array}{c}66 \\
190\end{array}$ & $\begin{array}{c}71 \\
406\end{array}$ & 73708 & $\begin{array}{c}83 \\
208\end{array}$ & $\begin{array}{c}78 \\
673\end{array}$ & \\
\hline $\begin{array}{l}\text { Urals bbl/ } \\
\text { doll.*** }\end{array}$ & 93.6 & 60.7 & 78.1 & 109.6 & 110.6 & 108.0 & 97.6 & 51.0 & 96.0 & 50.0 & \\
\hline
\end{tabular}

* Treasury data.

** Federal Law of 14.12.2015 № 359-FZ “On Federal Budget for 2016".

*** Annual average.

Sources: Federal Treasury; Gaidar Institute calculations.

the one-year document was based on the price of crude oil at $\$ 50$ per barrel. Approved volume of expenditure reached $20.5 \%$ of GDP up 1 p.p. of GDP of the original calculations. As a result, the federal budget deficit went up to $3 \%$ of GDP against $0.6 \%$ of GDP in the original version. However, taking into account the fact that in January 2016 the price of crude oil fell below $\$ 30$ per barrel, there is a high probability that even in case of one-year budget it will impossible to avoid adjustments in the course of the budget year.

Main feature of the 2016 budget will be the need to come to terms with the new normal of very low crude oil prices - around \$30-40 per barrel (possibly less) in the context that the federal budget is approved on an assumption that the price of oil stands at $\$ 50$ per barrel and its balancing according to the Finance Ministry comes at $\$ 82$ per barre ${ }^{1}$.

In the absence of adequate measures of operative (for 2016) and strategic response (2017-2019) against the backdrop of persistence of current crude oil prices in the medium term, the budget deficit can double in 2016 amid complete depletion of the Reserve Fund assets.

The Finance Ministry submitted an initiative for approval, which envisages escrow or withdrawal of budget funds unless as of 1 October there are contracts within financing budgetary spending. This measure is aimed at increasing spending discipline in the course of a fiscal year in order to eliminate

1 http://www.minfin.ru/ru/\#ixzz3yTTiNNKR 
spending of up to $25 \%$ of annual limits during the last months of the year. Budgetary spending in the end of the year are mostly ineffective and very often is linked with budget disbursement before the year-end at any cost.

For 2016, anti-crisis plan is aimed at the support of key sectors of the economy. The RF government estimates this plan in excess of Rb $827 \mathrm{bn}$. It is projected to continue supporting those sectors of the economy, which boast of high import substitution potential. In January 2016, were discussed measures to support three industries were discussed: automobile (tentatively $\mathrm{Rb}$ 20 bn for H1 2016 and Rb 5bn for 2016 as a whole of additional subsidies ${ }^{1}$ ), transport machine building and light industry (around Rb 600 mn). Mainly, support measures were directed at production incentives and supporting demand for these industries' output. Moreover, they were talking about supporting construction and agriculture (within 'anti-crisis plan' - Rb 5.1bn). However, the list of measures, industries - recipients of assistance as well as volumes of funds were not finalized. In January 2016, they were developing approval procedures for additional funds ${ }^{2}$.

Within expenditure obligations revision, the RF government plans to slash the approved expenditure volume in 2016. For example, plans regarding federal spending optimization can comprise ten percent reduction across all unprotected budget items, which will allow to save according to the RF government around $\mathrm{Rb} 500-700 \mathrm{bn}$. Officially, this is not about proportional reduction across all items but solely about their ineffective component. Continuation of a technical slashing of expenditure, for example, on educational institutions and health care facilities can place certain institutions in a position when they will lack funds to cover all current costs (except wages). Consequently, with the reform of the budget institution network a simple reduction of its funding carries big risks. That is why, it will be most important during the new budget expenditure revision to avoid another "technical cut" (in all its relative simplicity) and reveal really inefficient budget expenses. It is important to put into practice variable-based approach into the budget planning when those expenses, which are subject to reduction in the event macroeconomic conditions turn out worse than projections are predetermined (in Russian practice this could be implemented within the state program with picking up "mandatory" and "additional" parts in each program).

Let us study the parameters of the 2015 federal budget execution. As a whole, the volume of tax revenues contracted considerably: -2.6 p.p. of GDP against 2014.

While analyzing the structure of actual tax revenues flow of the federal budget (Table 2) one can note growth of revenues in relative terms generated from Mineral Extraction Tax (MET) (+0.3 p.p. of GDP), VAT of goods sold on the RF territory ( +0.2 p.p. of GDP) and generated from corporate income $\operatorname{tax}(+0.1$ p.p. of GDP. Revenues growth generated by MET is due to a drastic increase from the turn of 2015 of the MET base rate on crude oil from Rb 493 to $\mathrm{Rb} 766$ per ton, which was implemented within the "tax maneuver".

Customs duties by the period-end for 2015 have contracted significantly by 3.2 p.p. of GDP, which is due to the fall of crude oil prices and reduction of imports. Moreover, customs receipts have shrunk due to the reduction since the turn of 2015 of the effective marginal export customs duties rates on

1 From the additional assets allocated in the budget for targeted support of certain sectors.

2 http://bujet.ru/article/288770.php 
crude oil to $42 \%$ against $59 \%$ in 2014 . This measure was implemented within the "tax maneuver". The volume of receipts generated from VAT on goods sold on the RF territory in 2015 shows insignificant growth by 0.2 p.p. of GDP. Furthermore, proceeds generated from VAT on goods imported into the RF territory and from excises (both "imported" and "domestic") have remained as a share of GDP at the level of 2014.

Table 2

MAIN TAX REVENUES IN THE FEDERAL BUDGET IN 2014-2015

\begin{tabular}{|c|c|c|c|c|c|}
\hline & $\begin{array}{l}\text { Jan } \\
\text { Dece } \\
20\end{array}$ & $\begin{array}{l}\text { ry- } \\
\text { nber } \\
5\end{array}$ & $\begin{array}{l}\text { Janı } \\
\text { Dece } \\
20\end{array}$ & $\begin{array}{l}\text { ary- } \\
\text { nber } \\
14\end{array}$ & 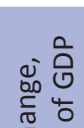 \\
\hline & $\mathrm{Rb} b n$ & $\%$ GDP & $\mathrm{Rb} b n$ & $\%$ GDP & i \\
\hline $\begin{array}{l}\text { Tax revenues, total, } \\
\text { including }\end{array}$ & 11877 & 16.1 & 13385 & 18.7 & -2.6 \\
\hline Corporate income tax & 491 & 0.7 & 411 & 0.6 & 0.1 \\
\hline $\begin{array}{l}\text { VAT on merchandise sold } \\
\text { on the RF territory }\end{array}$ & 2443 & 3.3 & 2181 & 3.1 & 0.2 \\
\hline $\begin{array}{l}\text { VAT on merchandise import- } \\
\text { ed into the RF territory }\end{array}$ & 1838 & 2.5 & 1750 & 2.5 & 0.0 \\
\hline $\begin{array}{l}\text { Excises on merchandise manu- } \\
\text { factured on the RF territory }\end{array}$ & 528 & 0.7 & 521 & 0.7 & 0.0 \\
\hline $\begin{array}{l}\text { Excises on merchandise import- } \\
\text { ed into the RF territory }\end{array}$ & 54 & 0.1 & 72 & 0.1 & 0.0 \\
\hline MET & 3160 & 4.3 & 2858 & 4.0 & 0.3 \\
\hline $\begin{array}{l}\text { Revenues from the foreign eco- } \\
\text { nomic activity (customs dues) }\end{array}$ & 3294 & 4.5 & 5463 & 7.7 & -3.2 \\
\hline
\end{tabular}

Sources: RF Treasury; Gaidar Institute calculations.

Table 3 provides results of the 2015 federal budget execution broken down by the function cost.

Table 3

FEDERAL BUDGET EXPENDITURE FOR 2014-2015

\begin{tabular}{|c|c|c|c|c|c|}
\hline & 20 & & & & \\
\hline & $\mathrm{Rb} b n$ & $\%$ GDP & $\mathrm{Rb}$ bn & $\%$ GDP & $\stackrel{\overline{0}}{\frac{\bar{c}}{U}} \frac{\dot{2}}{\dot{2}}$ \\
\hline Expenditure total, of which: & $\begin{array}{c}15 \\
500.8\end{array}$ & 21.0 & $\begin{array}{c}14 \\
830.6\end{array}$ & 20.8 & 0.2 \\
\hline General state issues & 1101.4 & 1.5 & 934.7 & 1.3 & 0.2 \\
\hline National defense & 3181.2 & 4.3 & 2479.1 & 3.5 & 0.8 \\
\hline National security and law enforcement & 1966.0 & 2.7 & 2086.2 & 2.9 & -0.2 \\
\hline National economy & 2160.9 & 2.9 & 3062.9 & 4.3 & -1.4 \\
\hline Housing and utilities sector & 141.9 & 0.2 & 119.6 & 0.2 & 0 \\
\hline Environmental conservation & 49.7 & 0.07 & 46.4 & 0.06 & 0.01 \\
\hline Education & 610.6 & 0.8 & 638.3 & 0.9 & -0.1 \\
\hline Culture, cinematography & 89.2 & 0.1 & 97.8 & 0.1 & 0 \\
\hline Healthcare & 516.2 & 0.7 & 535.6 & 0.8 & -0.1 \\
\hline Social policy & 4264.6 & 5.8 & 3452.4 & 4.8 & 1.0 \\
\hline Physical fitness and sports & 72.9 & 0.1 & 71.0 & 0.1 & 0 \\
\hline Mass media & 82.1 & 0.1 & 74.8 & 0.1 & 0 \\
\hline Servicing state and municipal debt & 581.9 & 0.8 & 415.6 & 0.6 & 0.2 \\
\hline Inter-budget general transfers & 682.0 & 0.9 & 816.1 & 1.1 & -0.2 \\
\hline
\end{tabular}

Sources: RF Finance Ministry; Gaidar Institute calculations. 
On the whole, the federal budget expenditure for 2015 went up 0.2 p.p. of GDP against 2014. Spending volumes were registered across the following items: "Social policy" 91 p.p. of GDP), "National defense" (0.8 p.p. of GDP), "General state issues" (0.2 p.p. of GDP) and "Servicing of public debt" (0.2 p.p. of GDP).

The most tangible reduction affected item "National economy" (-1.4 p.p. of GDP). Significant gap in the volume of budget spending on support of the economy in 2014 and 2015 is due to assets contribution by end-2015 to the Deposit Insurance Agency (DIA) in the amount of one trillion rubles ${ }^{1}$. Allocation of funds was envisaged by the measures of state support of the banking sector. Without funds transferred to DIA, the volume of spending along the item "National economy" for 2014 as a share of GDP is comparable with its volume for 2015 (2.9\% of GDP).

Federal budget spending reduction for 2015 also affected items: "National defense and law enforcement" (-0.2 p.p. of GDP), "Inter-budget general transfers" (-0.2 p.p. of GDP) and "Education" (-0.1 p.p. of GDP).

Table 4 represents dynamic of the federal budget expenditure broken by operation in the state governance sector.

Table 4

FEDERAL BUDGET EXPENDITURE 2011-2015

\begin{tabular}{|c|c|c|c|c|c|}
\hline & 2011 & 2012 & 2013 & 2014 & 2015 \\
\hline Expenditure total, $\mathrm{Rb}$ bn & 10935 & 12891 & 13343 & 14832 & 15501 \\
\hline Growth in real terms, \% & -0.3 & 12.2 & -3.0 & 3.1 & -9.5 \\
\hline \multicolumn{6}{|l|}{ of which: } \\
\hline $\begin{array}{l}\text { Investment charac- } \\
\text { ter expenses, Rb bn }\end{array}$ & 1660 & 1753 & 1659 & 1773 & 2313 \\
\hline Growth in real terms, \% & 7.5 & 0.5 & -11.4 & -0.9 & 13.0 \\
\hline $\begin{array}{l}\text { Including stock value growth } \\
\text { and other forms of par- } \\
\text { ticipation in capital }\end{array}$ & 410 & 505 & 315 & 264 & 226 \\
\hline Growth in real terms, \% & 14.4 & 17.3 & -41.6 & -22.3 & -25.9 \\
\hline Current expenses, Rb bn & 9275 & 11137 & 11684 & 13059 & 13188 \\
\hline Growth in real terms, \% & -1.6 & 14.3 & -1.7 & 3.7 & -12.6 \\
\hline
\end{tabular}

The federal budget expenditure for 2015 against 2014 went down by $9.5 \%$ in real terms. Current expenses take a large share in the federal budget expenditure structure. Largely their decline $(-12.6 \%)$ caused actual contraction of the overall expenditure amount. Investment spending, on the contrary, demonstrate growth in real terms by $13 \%$ for 2015 against decline by $-0.9 \%$ for 2014. Significant growth of budget investment was ensured by an increase (around 38\%) along item "Increase in value of fixed assets", which was determined, most likely, by an increase of expenses of state defense order. It is difficult to make price assessment due to a classified component of defense expenditure. However, even in case of a disclosed component of defense expenditure by the period-end for 9 months of 2015 growth of the investment component reached around $48 \%$.

1 In December 2014, these funds were transferred via issue of OFZ and allocated for the banks recapitalization. By way of these contribution DIA received the right to recapitalize too big to fail banks, which capital is no less than Rb 100bn. 